\title{
Cerebrospinal fluid neurofilament light chain differentiates behavioural variant frontotemporal dementia progressors from 'phenocopy' non-progressors
}

\author{
Dhamidhu Eratne ${ }^{\mathrm{a}, \mathrm{b}, \mathrm{c}}$ \\ Michael Keem ${ }^{a, b}$ \\ Courtney Lewis ${ }^{a, b}$ \\ Matthew Kang a,b \\ Mark Walterfang a,b,c \\ Samantha Loi ${ }^{a, b}$ \\ Wendy Kelso ${ }^{a}$ \\ Claire Cadwallader ${ }^{\text {a }}$ \\ Samuel F Berkovic ${ }^{d}$ \\ Qiao-Xin $\mathrm{Li}^{\mathrm{C}}$ \\ Colin L Masters ${ }^{c}$ \\ Steven Collins ${ }^{c}$ \\ Alexander Santillo ${ }^{e}$ \\ Dennis Velakoulis $a, b$ \\ The MiND Study Group \\ (The MiND Study Group Collaborators listed in Appendix 1) \\ a: Neuropsychiatry, Royal Melbourne Hospital, Parkville, VIC, Australia \\ b: Melbourne Neuropsychiatry Centre \& Department of Psychiatry, University of Melbourne, Parkville, \\ VIC, Australia \\ c: National Dementia Diagnostics Laboratory, The Florey Institute of Neuroscience and Mental Health, \\ Parkville, VIC, Australia \\ d: Epilepsy Research Centre, Department of Medicine, Austin Health, The University of Melbourne, \\ Heidelberg, VIC, Australia \\ d: Australian National Creutzfeldt-Jakob Disease Registry, Florey Institute of Neuroscience and \\ Mental Health and Department of Medicine, The University of Melbourne, Parkville, VIC, Australia \\ e: Clinical Memory Research Unit, Department of Clinical Sciences Malmö, Lund University, \\ Sölvegatan 18, Sweden
}

\section{Corresponding author:}

Dr Dhamidhu Eratne

\section{BHB MBChB FRANZCP}

Neuropsychiatry, Royal Melbourne Hospital, 300 Grattan St, Parkville VIC 3050, Australia

dhamidhu.eratne@mh.org.au

Tel: +61 393428750

\section{Submission Type: Article}

Title character count: 136

Abstract word count: 250

Number of references: 40

Number of figures: 3

Number of tables: 2

Word Count (excluding title page, abstract, references, figures and tables): 3202

\section{Keywords:}


medRxiv preprint doi: https://doi.org/10.1101/2022.01.14.22269323; this version posted January 15, 2022. The copyright holder for this preprint (which was not certified by peer review) is the author/funder, who has granted medRxiv a license to display the preprint in perpetuity.

All rights reserved. No reuse allowed without permission.

\section{ORCID iD}

Dhamidhu Eratne: https://orcid.org/0000-0002-3226-7645

\section{ACKNOWLEDGEMENTS AND FUNDING SOURCES}

We are grateful for funding that supported this work: the Trisno Family Research Grant in Old Age

Psychiatry, three NorthWestern Mental Health Research Seed Grants, MACH MRFF RART 2.1, and NHMRC (1185180). Finally, the authors would like to thank all the patients and their families for their participation.

The corresponding author had full access to all the data in the study and had final responsibility for the decision to submit for publication.

\section{DECLARATION OF INTERESTS AND FINANCIAL DISCLOSURES}

All the authors have nothing to disclose.

Statistical Analysis conducted by: Dr Dhamidhu Eratne and Dr Michael Keem 


\section{Abstract}

\section{Background:}

Distinguishing behavioural variant frontotemporal dementia (bvFTD) from non-neurodegenerative 'nonprogressor', 'phenocopy' mimics of frontal lobe dysfunction, can be one of the most challenging clinical dilemmas. A biomarker of neuronal injury, neurofilament light chain (NfL), could reduce misdiagnosis and delay.

\section{Methods:}

Cerebrospinal fluid (CSF) NfL, amyloid beta 1-42 (AB42), total and phosphorylated tau (T-tau, P-tau) levels were examined in patients with an initial diagnosis of bvFTD. Based on follow up information, patients were categorised as Progressors. Non-Progressors were subtyped in to Phenocopy Non-Progressors (nonneurological/neurodegenerative final diagnosis), and Static Non-Progressors (static deficits, not fully explained by non-neurological/neurodegenerative causes).

\section{Results:}

Forty-three patients were included: 20 Progressors, 23 Non-Progressors (15 Phenocopy, 8 Static), 20 controls. NfL concentrations were lower in Non-Progressors (Non-Progressors Mean, $M=554 \mathrm{pg} / \mathrm{mL}$, 95\%Cl:[461, 675], Phenocopy Non-Progressors M=459pg/mL, 95\%Cl:[385, 539], Static Non-Progressors $M=730 \mathrm{pg} / \mathrm{mL}, 95 \% \mathrm{Cl}:[516,940])$, compared to bvFTD Progressors (M=2397pg/mL, 95\%Cl:[1607, 3332]). NfL distinguished Progressors from Non-Progressors with the highest accuracy (area under the curve 0.92, $90 \% / 87 \%$ sensitivity/specificity, $86 \% / 91 \%$ positive/negative predictive value, $88 \%$ accuracy). Static NonProgressors tended to have higher T-tau and P-tau levels compared to Phenocopy Non-Progressors.

\section{Conclusion:}

This study demonstrated strong diagnostic utility of CSF NfL to distinguish bvFTD from phenocopy nonprogressor variants, at baseline, with high accuracy, in a real-world clinical setting. This has important clinical implications, to improve outcomes for patients and clinicians facing this challenging clinical dilemma, as well as for healthcare services, and clinical trials. Further research is required to investigate heterogeneity within the non-progressor group and potential diagnostic algorithms, and prospective studies are underway assessing plasma NfL 


\section{Introduction}

Determining the underlying cause of cognitive and behavioural change associated with functional decline is often diagnostically challenging for clinicians. Even in centres with gold-standard multidisciplinary and multimodal investigations, individuals still face several years of diagnostic uncertainty, misdiagnosis, and delay. Diagnostic delay is greatest in patients with younger onset (symptom onset before 65 years) dementia who frequently present with psychiatric or behavioural symptoms [1-4]. In particular, the behavioural, personality and executive dysfunction symptoms of behavioural variant frontotemporal dementia (bvFTD) can be difficult to distinguish from primary psychiatric symptoms and other non-neurodegenerative causes of frontal lobe dysfunction [4-12].

An increasing body of literature has identified individuals who can appear clinically to have bvFTD, meet established diagnostic criteria for bvFTD, but who do not have the expected clinical, neuropsychological and neuroimaging progression over time. Various terms and definitions have been used for group, such as "bvFTD phenocopies", "mild behavioural impairment", and "nonprogressors", sometimes inconsistently, and a consensus has yet to be reached [13-18]. While people with a very slowly progressive bvFTD associated with the C9orf72 genetic mutation have been identified [19-23], it is likely that this 'non-progressors' group is aetiologically heterogenous, comprising people with primary psychiatric disorders or people with a mid-life stress related exacerbation of underlying personality, relationship or neurocognitive vulnerabilities. Regardless of the aetiology of phenocopy non-progressors, there is strong consensus that it is not benign, associated with high functional impact, patient distress and carer burden [13]. Differentiating between progressors and non-progressors at initial presentation, is challenging $[11,15,18]$. International consensus diagnostic criteria, which remain the gold standard for the diagnosis of bvFTD, involve diagnostic stratification into possible, probable or definite bvFTD [11,24]. Given that it can take years to reach a definitive diagnosis and the implications for treatment, prognosis, genetic counselling, and wider occupational and psychosocial outcomes, there is a critical need for earlier, accurate diagnostic differentiation. A biomarker that could assist in distinguishing between bvFTD progressors and nonprogressors at baseline assessment could significantly improve outcomes for patients, their families, clinical trials, and healthcare systems. 
medRxiv preprint doi: https://doi.org/10.1101/2022.01.14.22269323; this version posted January 15, 2022. The copyright holder for this preprint (which was not certified by peer review) is the author/funder, who has granted medRxiv a license to display the preprint in perpetuity.

All rights reserved. No reuse allowed without permission.

Neurofilament light (NfL) is one of three subunits of a neuroaxonal cytoskeletal protein common to myelinated axons, with elevated levels in cerebrospinal fluid (CSF) and blood associated with neuronal injury and a marker of diagnosis, staging and prognosis, in a diverse range of neurological and neurodegenerative disorders [25-31]. Numerous studies have demonstrated elevated CSF and blood NfL in bvFTD compared to controls, as well as primary psychiatric disorders [29-38]. Recent expert consensus guidelines and recommendations have recommended $\mathrm{NfL}$ as a biomarker to assist with differentiating bvFTD from primary psychiatric disorders [11]. Our previous studies have demonstrated the ability for CSF NfL to distinguish bvFTD from primary psychiatric disorders, with high accuracy, in a real-world clinical setting, where patients who were ultimately diagnosed with a primary psychiatric illness were referred specifically for assessment of a possible neurodegenerative dementia [30] [Eratne et al., Alzheimer's \& Dementia, in press, 2021].

To our knowledge, no studies have investigated the diagnostic utility of NfL to distinguish bvFTD from non-progressor phenocopy syndromes, where there was an initial clinical suspicion for and diagnosis of bvFTD, in real-world clinical settings. The primary aim of this study was to explore the diagnostic utility of CSF NfL in differentiating progressive (neurodegenerative) bvFTD from non-progressive syndromes that presented with behavioural, psychiatric, neurological, cognitive and functional impairments, and who met diagnostic criteria for at least possible bvFTD. Secondary aims included examining differences in clinical variables between diagnostic groups, and determining the diagnostic utility of NfL and other biomarkers in differentiating between possible subtypes of non-progressors.

\section{Methods}

This was a retrospective, longitudinal cohort study involving patients referred to Neuropsychiatry, The Royal Melbourne Hospital, a tertiary state-wide specialist service, for comprehensive multidisciplinary and multimodal diagnostic assessment of possible dementia, and ongoing management.

Inclusion criteria were: (1) A diagnosis of possible, probable or definite bvFTD [24] made at any time over the course of assessment with the service or follow-up, (2) CSF was collected as part of their 
medRxiv preprint doi: https://doi.org/10.1101/2022.01.14.22269323; this version posted January 15, 2022. The copyright holder for this preprint (which was not certified by peer review) is the author/funder, who has granted medRxiv a license to display the preprint in perpetuity.

All rights reserved. No reuse allowed without permission.

diagnostic work-up between June 2009 and December 2020, and remnant CSF was available for NfL analysis, (3) available formalised follow-up information for a minimum of 12 months.

Patients were assessed in inpatient and/or outpatient settings by a multidisciplinary team including neuropsychiatrists, neurologists, neuropsychologists, nurses, occupational therapists, speech pathologists, and social workers, as well as receiving multimodal investigations including brain MRI and SPECT/FDG-PET, and CSF analysis for Alzheimer's disease biomarkers. A consensus goldstandard diagnosis of possible, probable or definite bvFTD was made based on established diagnostic criteria [24]. With ongoing follow-up and longitudinal multidisciplinary assessments and multimodal investigations, this diagnosis could be revised as patients' conditions changed, and as new data was made available.

Patients' medical records were accessed, and data extracted included detailed demographic and clinical variables (Table 1), initial diagnosis, and most recent diagnosis based on serial assessments including obtaining follow up information from clinicians from other services. Structured symptom rating scales were not used consistently in clinical practice over the study period.

While acknowledging some of the issues with various current terminology and definition, for the purpose of this study we elected to use terminology commonly used in the literature and in clinical practice to describe the clinical phenotypes and progression over time - Progressors and NonProgressors (Figure 1).

Progressors were defined as patients who were initially diagnosed with bvFTD, and retained the bvFTD diagnosis on follow up. In keeping with the retained bvFTD diagnosis on follow up, Progressors had either a) clear progression (clinical and/or neuroimaging and/or bedside cognitive/neuropsychological testing, and/or functioning), and/or b) their diagnostic classification strength progressed (i.e. from possible to probable, possible/probable to definite).

Non-Progressors were patients initially diagnosed with bvFTD, but who did not show evidence of progression on follow up (clinical and/or neuroimaging and/or bedside cognitive/neuropsychological testing, and/or functioning). To explore possible heterogeneity within the Non-Progressor Group, Non- 
medRxiv preprint doi: https://doi.org/10.1101/2022.01.14.22269323; this version posted January 15, 2022. The copyright holder for this preprint (which was not certified by peer review) is the author/funder, who has granted medRxiv a license to display the preprint in perpetuity.

All rights reserved. No reuse allowed without permission.

Progressors were further subtyped in to Phenocopy Non-Progressor, and Static Non-Progressor. Phenocopy Non-Progressors were defined as patients where the initial bvFTD diagnosis was eventually completely rescinded, a neurodegenerative disorder was deemed unlikely, and the final diagnosis was of one of a primary psychiatric / psychological / non-neurodegenerative disorder. Static Non-Progressors were patients where although there was no clear evidence of progression, there was a neurological/neurodegenerative cause was still suspected as the cause of static cognitive and functional impairments, and unlike the Phenocopy Non-Progressors, there was no clear primary psychiatric / psychological or non-neurodegenerative disorder diagnosis to fully explain the presentation. Two authors (Eratne, Keem) independently performed file reviews and categorisation. Data extraction and diagnostic categorisation was done blinded to NfL and other biomarker data.

CSF analysis has been previously described [30] [Eratne et al., Alzheimer's \& Dementia, in press, 2021]. Briefly. all participants had CSF collected in a polypropylene tube during their initial assessment, analysed in duplicate for Aß42, T-tau and P-tau at the National Dementia Diagnostic Laboratory (NDDL), Melbourne, using INNOTEST ELISA (Fujirebio, Ghent, Belgium), remaining samples stored at $-80^{\circ} \mathrm{C}$. NfL was analysedat NDDL via NF-light ELISA (UmanDiagnostics, Umea, Sweden), according to the manufacturer protocols. Diluted CSF $(1+1)$ and reconstituted standards were added to the plate in duplicate, incubated, washed. Samples displaying concentrations above the highest standard point were further diluted and re-assayed. Two internal controls of pooled CSF were included in each NfL plate. Mean intra-assay coefficient and inter-assay coefficient of variation was $6.2 \%$ and $11.3 \%$, respectively.

Healthy control data was available from the 'Australian Imaging, Biomarker \& Lifestyle' (AIBL) study, previously described [30]. Briefly, criteria for inclusion were: age at time of CSF sampling less than 70; no psychiatric or neurological diagnosis at time of CSF sampling nor in 18 months prior; negative amyloid PET; normal CSF A $\beta 1$-42, T-tau and P-tau levels; classification as healthy control based on formal neuropsychology assessment.

This study was approved by Human Research Ethics Committees at Melbourne Health (2016.038: approval for retrospective biomarker analyses; 2018.371, 2020.142: participants provided consent), and Florey Institute of Neurosciences and Mental Health (1648441.1). 
medRxiv preprint doi: https://doi.org/10.1101/2022.01.14.22269323; this version posted January 15, 2022. The copyright holder for this preprint (which was not certified by peer review) is the author/funder, who has granted medRxiv a license to display the preprint in perpetuity.

All rights reserved. No reuse allowed without permission.

\section{Statistical analysis}

Statistical analysis was undertaken using SPSS 27 and 28. General linear models (GLMs) were performed for comparison of NfL, A $\beta 1-42$, T-tau and P-tau in Progressors versus Non-Progressors, with age as a covariate. ROC curve analyses determined areas under the curve (AUC), Youden's method to determine optimal cut-off, sensitivity and specificity of biomarkers in distinguishing between groups. GLMs had bias-corrected and accelerated (BCa) confidence intervals (Cls) derived via nonparametric bootstrapping, 1000 replicates. Statistical significance was defined as any $\mathrm{Cl}$ not capturing the null-hypothesis value (at the $95 \%$ level).

\section{$\underline{\text { Results }}$}

\section{Study cohort details and clinical variables (Table 1)}

Forty-three patients met inclusion criteria: 20 bvFTD Progressors, and 23 Non-Progressors (comprising 15 Phenocopy Non-Progressors, 8 Static Non-Progressors). The mean age at initial assessment, age at CSF collection, age at onset, and proportion of females, were not significantly different between the patient groups. All patient groups had similar, several years of clinical follow up information available after the initial bvFTD diagnosis (mean 3 years). 20 controls were included, mean age 66 years.

Non-Progressors had a higher proportion of possible bvFTD at initial diagnosis, compared to Progressors ( $78 \%$ vs. $15 \%)$, and thus a lower proportion of probable bvFTD ( $22 \%$ vs. $85 \%)$. Several clinical variables were more frequent in all Non-Progressors, Phenocopy and Static Non-Progressors, compared to Progressors: substance use (approximately double in Non-Progressors), previous psychiatric diagnoses (close to $90 \%$ in Non-Progressors, versus 35\% in Progressors), and nonpsychotic psychiatric symptoms at presentation (over $80 \%$ in Non-Progressors, $60 \%$ in Progressors). New psychiatric symptoms (defined as within 5 years of presentation) were higher in NonProgressors, particularly Phenocopy Non-Progressors (80\% vs. 20\% Progressors). All patients had functional impairment with low Global Assessment of Functioning (GAF) scores, and the majority of patients in all groups had abnormalities on neurological examination. All Progressors had abnormal 
medRxiv preprint doi: https://doi.org/10.1101/2022.01.14.22269323; this version posted January 15, 2022. The copyright holder for this preprint (which was not certified by peer review) is the author/funder, who has granted medRxiv a license to display the preprint in perpetuity.

All rights reserved. No reuse allowed without permission.

MRI (and almost all had abnormal SPECT/PET), and the majority of Non-Progressors had abnormalities on neuroimaging (although not always frontotemporal suggestive of bvFTD). All patient groups had similar impairments on the Neuropsychiatry Unit Cognitive Assessment Tool (NUCOG) bedside cognitive screening instrument total score and cognitive subdomains. Although Progressors had slightly poorer performance on the NUCOG total score and executive function domain, this was not statistically different. No patients, regardless of Progressor or Non-Progressor status, had normal performance on formal neuropsychological assessment.

\section{CSF neurofilament light chain and other biomarkers}

NfL concentrations were lower in Non-Progressors (Non-Progressors Mean, $M=554 \mathrm{pg} / \mathrm{mL}$, 95\%Cl:[461, 675], Phenocopy Non-Progressors M=459pg/mL, 95\%Cl:[385, 539], Static NonProgressors $M=730 \mathrm{pg} / \mathrm{mL}, 95 \% \mathrm{Cl}:[516,940]$ ), compared to bvFTD Progressors ( $M=2397 \mathrm{pg} / \mathrm{mL}$, 95\%Cl:[1607, 3332]) (Table 2 and Figure 2). Although lowest levels and the narrowest range was seen in the Phenocopy Non-Progressor group, levels were not statistically different to Static NonProgressors (GLM mean difference, Mdiff=192, 95\%Cl:[124, 518]). The differences in NfL levels between Progressors and other groups were large: Progressors versus all Non-Progressors (GLM mean difference, Mdiff=1817, 95\%Cl:[988, 2745]), versus Phenocopy Non-Progressors (MDiff=1885, 95\%Cl:[1093, 2721]), versus Static Non-Progressors (Mdiff=1694, 95\%Cl:[900, 2545]), and versus controls (Mdiff=2097, 95\%Cl:[982, 3290]).

T-tau levels were higher in Progressors ( $\mathrm{M}=238 \mathrm{pg} / \mathrm{mL}, 95 \% \mathrm{Cl}:[187,298])$ compared to Phenocopy Non-Progressors (M=127pg/mL, 95\%Cl:[96, 157], Mdiff=108, 95\%Cl:[44, 176]), but not Static NonProgressors (M=273pg/mL, 95\%Cl:[178, 404]). Static Non-Progressors had higher T-tau levels than Phenocopy Non-Progressors (Mdiff=139, 95\%Cl:[26, 298]), Table 2, Supplementary Figure 1.

Static Non-Progressors also had higher P-tau levels than Phenocopy Non-Progressors (Mdiff=21, 95\%Cl:[3, 42]), Table 2, Supplementary Figure 2. A 342 levels were lower in Phenocopy NonProgressors compared to Static Non-Progressors (Mdiff=218, 95\%Cl:[77, 363]) and controls (Mdiff=170, 95\%Cl:[18, 300]), Table 2, Supplementary Figure 3. There were no sex differences in any biomarker levels. 
medRxiv preprint doi: https://doi.org/10.1101/2022.01.14.22269323; this version posted January 15, 2022. The copyright holder for this preprint (which was not certified by peer review) is the author/funder, who has granted medRxiv a license to display the preprint in perpetuity.

All rights reserved. No reuse allowed without permission.

\section{NfL, T-tau, P-tau and Aß1-42 as diagnostic tests}

NfL distinguished bvFTD Progressors from all Non-Progressors with the highest accuracy (area under the curve, AUC: $0.92,90 \%$ sensitivity, $87 \%$ specificity at optimal cut-off of $726 \mathrm{pg} / \mathrm{mL}$ ), superior to Ttau (AUC 0.69, AUC difference 0.23, 95\%Cl:[0.09, 0.38], 72\% sensitivity, 73\% specificity, cut-off $192 \mathrm{pg} / \mathrm{mL}$ ), Figure 3 and Supplementary Material. NfL at the $726 \mathrm{pg} / \mathrm{mL}$ cut-off distinguished ND from PSY with $86 \%$ positive predictive value (PPV), 91\% negative predictive value (NPV), 6.8 positive likelihood ratio (LR+ve), 0.11 negative likely ratio (LR-ve), accurately classifying $88 \%$ (38/43) of patients.

NfL performed particularly well in distinguishing Progressors from Phenocopy Non-Progressors (AUC $0.99,90 \%$ sensitivity, $100 \%$ specificity at cut-off of $726 \mathrm{pg} / \mathrm{mL}$, and at a cut-off of $583 \mathrm{pg} / \mathrm{mL}, 100 \%$ sensitivity, $87 \%$ specificity, 100\% PPV, $88 \%$ NPV, 0.10 LR-ve, 94\% accuracy). NfL was once again superior to T-tau for this distinction (AUC difference $0.18,95 \% \mathrm{Cl}:[0.02,0.33]$ ).

NfL had lower specificity in distinguishing Progressors from Static Non-Progressors (AUC 0.82, 90\% sensitivity, $63 \%$ specificity, cut-off $716 \mathrm{pg} / \mathrm{mL}$ ). Combining NfL and $A \beta 42$ in to an NfL:A 342 ratio resulted in improved AUC and specificity (AUC 0.88, 73\% sensitivity, 100\% specificity, cut-off 1.40), although this was not statistically significant (AUC difference 0.06, 95\%Cl:[-0.24, 0.11]). More information on these other comparisons are available in Supplementary Material.

\section{Discussion}

Our study found that baseline CSF NfL levels differentiated bvFTD from non-progressive 'phenocopies', with high accuracy, in a cohort of patients from a real-world clinical setting. Our findings have important clinical translation implications, supporting the use of CSF NfL, at initial assessment, as a sensitive and specific biomarker in predicting and distinguishing, progressive bvFTD from non-progressive and mimicking syndromes that have historically been subsumed under the 'phenocopy bvFTD' label. This is a common, challenging clinical dilemma, with patients often needing several years and multiple assessments and investigations before a phenocopy 'nonprogressor' diagnosis can more confidently be made. 
medRxiv preprint doi: https://doi.org/10.1101/2022.01.14.22269323; this version posted January 15, 2022. The copyright holder for this preprint (which was not certified by peer review) is the author/funder, who has granted medRxiv a license to display the preprint in perpetuity.

All rights reserved. No reuse allowed without permission.

A novel aspect of our study was exploring Non-Progressors in more detail, given the likely heterogeneity within this group. We sub-categorised non-progressors in to 'Phenocopy NonProgressors', where a primary psychiatric/psychological non-neurodegenerative formulation was ultimately made, compared to 'Static Non-Progressors', where there was still clinical suspicion of a neurological/neurodegenerative cause for static cognitive and functional impairments. There has been speculation that this group may still have neurodegenerative aetiology, subclinical, or at an extreme slowly progressive end of a bvFTD spectrum. Our findings in the Static Non-Progressor group, of slightly higher NfL, and in particular higher total tau levels, compared to the Phenocopy NonProgressors, may be consistent with a subclinical bvFTD or another slowly progressive neurodegenerative or tau-related syndrome, albeit at a very low rate that is not demonstrated clearly on serial clinical and neuroimaging assessments. Interestingly, it was the Phenocopy Non-Progressor group that had lower AB42 levels, similar to levels seen in the bvFTD progressors. However, given the small number of Static Non-Progressors, caution is required in interpreting these exploratory findings. To help understand the possible heterogeneity in apparent non-progressors, further research in larger cohorts, with serial NfL levels, detailed clinical, biomarker, and genetic phenotyping, is warranted.

Our findings of overlap on a range of clinical variables at baseline, adds further weight to how challenging and complex the distinction between Progressors and Non-Progressors is, in real-world clinical practice. Bedside cognitive testing did not discriminate Progressors from Non-Progressors, and bvFTD Progressors had memory as well as executive function impairments. All Non-Progressors had impairments on neuropsychological assessment, and most Non-Progressors had abnormalities on structural and functional neuroimaging. These results, and our finding that Non-Progressors were more likely to only initially meet criteria for possible bvFTD, support other evidence on the greater uncertainty and diagnostic instability of possible bvFTD compared to probable/definite, and recommendations to be cautious about a diagnosis of bvFTD in the absence of neuroimaging changes consistent with bvFTD $[11,14,18]$. However, a significant proportion of Phenocopy NonProgressors $(33 \%, 5 / 15)$ had frontotemporal imaging changes that led to initially meeting criteria for probable bvFTD. Our findings would support increased suspicion of Non-Progressor in patients with a previous psychiatric history, and where psychiatric symptoms (separate to behavioural change) are 
medRxiv preprint doi: https://doi.org/10.1101/2022.01.14.22269323; this version posted January 15, 2022. The copyright holder for this preprint (which was not certified by peer review) is the author/funder, who has granted medRxiv a license to display the preprint in perpetuity.

All rights reserved. No reuse allowed without permission.

more prominent features at presentation. However, while there some differences at group levels, similar to what has been described in the literature [11,13,15,39], given the complexity and overlap between patient groups, no single clinical variable nor combination variables separated Progressors from Non-Progressors, as well as a single biomarker, NfL.

Our data supports an emerging consensus in the literature [10] that bvFTD phenocopies represented predominately by our Phenocopy Non-Progressors - may be considered a 'pseudodementia' syndrome with several common factors: male sex, personality vulnerabilities, significant social stressors that may injure self-identity, maladaptive coping strategies including significant substance misuse, chronic dysthymia or 'reactive' depression, and for some, the additional development of melancholic depressive features to constitute a 'double depression'. The majority of Non-Progressors in our cohort had a longstanding history of psychiatric symptoms (most commonly both non-melancholic/'reactive' and melancholic depressive symptoms), psychiatric history (typically major depressive disorder, PTSD), and Cluster B (especially borderline, histrionic and narcissistic) and Cluster C (primarily dependent and avoidant) personality constructs. Non-Progressors were more likely to have additional, new/superimposed symptoms, on this background, manifesting in context of interpersonal and psychosocial difficulties. In contrast, Static Non-Progressors did not have elevated rates of new psychiatric symptoms, but did have high rates of previous psychiatric diagnoses, and psychiatric symptoms at presentation, similar to Phenocopy Non-Progressors.

While this study is limited by its relatively small cohort size, our total case numbers were superior or comparable to several other retrospective cohort studies $[13,14,16,17]$, and contribute to the limited literature in this area, in particular regarding biomarkers. The retrospective design is an inherent limitation, mitigated by the consistency of multidisciplinary and multimodal assessments within a single tertiary service, and rigorous file review blinded to biomarkers and conducted by two investigators separately. Although our cohort had several years of follow up and serial, gold-standard multidisciplinary and multimodal assessments and diagnosis based on established diagnostic criteria, it is possible that longer follow up could have revealed more insights, and most patients lacked definitive genetic or pathological confirmation. We did not have phonemic fluency data on participants, which is a limitation of the NUCOG and our dataset, given other studies have found discriminatory potential [39]. The complexity of those patients with multifaceted symptomatology, comorbidities and 
medRxiv preprint doi: https://doi.org/10.1101/2022.01.14.22269323; this version posted January 15, 2022. The copyright holder for this preprint (which was not certified by peer review) is the author/funder, who has granted medRxiv a license to display the preprint in perpetuity.

All rights reserved. No reuse allowed without permission.

psychiatric histories included in this study that warranted referral to a tertiary neuropsychiatry service for assessment and diagnosis, may not necessarily be generalisable to other services. However, most such patients are seen within less sub-specialised services nor do most patients have access to such tertiary services, and in addition the broad inclusion criteria of this study helped mitigate this possibility, and is a key strength relative to much of the literature.

This study demonstrated the diagnostic utility of CSF NfL in distinguishing progressive bvFTD from non-progressive variants and mimics, at baseline, with high accuracy. As blood NfL correlates strongly with CSF levels [25,40], a simple blood test as a first-tier test at initial assessment could strongly support the diagnosis of progressive bvFTD, versus phenocopy or mimicking syndromes. This would be of immense benefit in primary and secondary, and rural healthcare settings where the resources and expertise required to reach a gold-standard consensus diagnosis of bvFTD are often unavailable. With further study, a speculative diagnostic algorithm incorporating CSF NfL, other biomarkers, and clinical variables, could be developed to not only accurately differentiate bvFTD from non-progressive variants, but further delineate truly non-neurodegenerative from other aetiologies (Supplementary Material). The capacity to accurately diagnose a progressive neurodegenerative illness and identify a potentially reversible condition mimicking bvFTD at time of initial assessment, could dramatically reduce delay and misdiagnosis, and improve outcomes for patients, their families, and healthcare systems. NfL, supplemented by T-tau and A $\beta 1-42$, promises to transform complex diagnosis and prognostication in the highly vulnerable cohort of patients presenting with frontotemporal neuropsychiatric impairments, and building on these findings, larger prospective studies assessing CSF and plasma biomarkers, are underway. 
medRxiv preprint doi: https://doi.org/10.1101/2022.01.14.22269323; this version posted January 15, 2022. The copyright holder for this preprint (which was not certified by peer review) is the author/funder, who has granted medRxiv a license to display the preprint in perpetuity.

All rights reserved. No reuse allowed without permission.

\section{References}

1 Loi SM, Goh AMY, Mocellin R, et al. Time to diagnosis in younger-onset dementia and the impact of a specialist diagnostic service. International Psychogeriatrics Published Online First: 2020. doi:10.1017/S1041610220001489

2 Draper B, Cations M, White F, et al. Time to diagnosis in young-onset dementia and its determinants: the INSPIRED study. International Journal of Geriatric Psychiatry 2016;31:1217-24. doi:10.1002/gps.4430

3 Bradford A, Kunik ME, Schulz P, et al. Missed and Delayed Diagnosis of Dementia in Primary Care: Prevalence and Contributing Factors. Alzheimer Disease \& Associated Disorders 2009;23:306-14. doi:10.1097/WAD.0b013e3181a6bebc

4 Woolley JD, Khan BK, Murthy NK, et al. The diagnostic challenge of psychiatric symptoms in neurodegenerative disease: Rates of and risk factors for prior psychiatric diagnosis in patients with early neurodegenerative disease. Journal of Clinical Psychiatry 2011;72:126-33. doi:10.4088/JCP.10m06382oli

5 Dols A. Identifying Specific Clinical Symptoms of Behavioral Variant Frontotemporal Dementia Versus Differential Psychiatric Disorders in Patients Presenting With a Late-Onset Frontal Lobe Syndrome. Journal of clinical psychiatry 2016;77:1189-200. doi:10.4088/JCP.15r10174

6 Vijverberg EGB, Gossink F, Krudop W, et al. The diagnostic challenge of the Late-onset frontal lobe syndrome: Clinical predictors for primary psychiatric disorders versus behavioral variant frontotemporal dementia. Journal of Clinical Psychiatry 2017;78:e1197-203. doi:10.4088/JCP.16m11078

7 Vijverberg EGB, Dols A, Krudop WA, et al. Diagnostic accuracy of the frontotemporal dementia consensus criteria in the late-onset frontal lobe syndrome. Dementia and Geriatric Cognitive Disorders 2016;41:2109. doi:10.1159/000444849

8 Chan HM, Stolwyk R, Kelso W, et al. Comparing neurocognition in severe chronic schizophrenia and frontotemporal dementia. Australian and New Zealand Journal of Psychiatry Published Online First: 2014. doi:10.1177/0004867414529477

9 Velakoulis D, Walterfang M, Mocellin R, et al. Frontotemporal dementia presenting as schizophrenia-like psychosis in young people: Clinicopathological series and review of cases. British Journal of Psychiatry 2009;194:298-305. doi:10.1192/bjp.bp.108.057034

10 Gossink FT, Dols A, Kerssens CJ, et al. Psychiatric diagnoses underlying the phenocopy syndrome of behavioural variant frontotemporal dementia. Journal of Neurology, Neurosurgery and Psychiatry 2016;87:64-8. doi:10.1136/jnnp-2014-308284

11 Ducharme S, Dols A, Laforce R, et al. Recommendations to distinguish behavioural variant frontotemporal dementia from psychiatric disorders. Brain 2020;143:1632-50. doi:10.1093/brain/awaa018

12 Tsoukra P, Velakoulis D, Wibawa P, et al. The Diagnostic Challenge of Young-Onset Dementia Syndromes and Primary Psychiatric Diseases: Results From a Retrospective 20-Year Cross-Sectional Study. J Neuropsychiatry Clin Neurosci 2021;:appineuropsych20100266. doi:10.1176/appi.neuropsych.20100266

13 Power C, Lawlor BA. The Behavioral Variant Frontotemporal Dementia Phenocopy Syndrome: A Review. J Geriatr Psychiatry Neurol 2021;34:196-208. doi:10.1177/0891988720924708

14 Power C, Hannigan O, Gibb M, et al. Phenocopy Frontotemporal Dementia: A Case Series from a National Memory Clinic and a Review of the Literature. Eur psychiatr 2017;41:S636-7. doi:10.1016/j.eurpsy.2017.01.1046 
medRxiv preprint doi: https://doi.org/10.1101/2022.01.14.22269323; this version posted January 15, 2022. The copyright holder for this preprint (which was not certified by peer review) is the author/funder, who has granted medRxiv a license to display the preprint in perpetuity.

All rights reserved. No reuse allowed without permission.

15 Hornberger M, Shelley BP, Kipps CMM, et al. Can progressive and non-progressive behavioural variant frontotemporal dementia be distinguished at presentation? Journal of Neurology, Neurosurgery \& Psychiatry 2009;80:591-3. doi:10.1136/jnnp.2008.163873

16 Hornberger $M$, Piguet $O$, Kipps $C$, et al. Executive function in progressive and nonprogressive behavioral variant frontotemporal dementia. Neurology 2008;71:1481-8. doi:10.1212/01.wnl.0000334299.72023.c8

17 Devenney E, Swinn T, Mioshi E, et al. The behavioural variant frontotemporal dementia phenocopy syndrome is a distinct entity - evidence from a longitudinal study. BMC Neurology 2018;18. doi:10.1186/s12883-018-1060-1

18 Devenney E, Bartley L, Hoon C, et al. Progression in Behavioral Variant Frontotemporal Dementia: A Longitudinal Study. JAMA Neurology 2015;72:1501-1501. doi:10.1001/jamaneurol.2015.2061

19 Brodtmann A, Cowie T, McLean C, et al. Phenocopy or variant: a longitudinal study of very slowly progressive frontotemporal dementia. Case Reports 2013;2013:bcr2012008077-bcr2012008077. doi:10.1136/bcr-2012-008077

20 Mattsson N, Rüetschi U, Pijnenburg YAL, et al. Novel cerebrospinal fluid biomarkers of axonal degeneration in frontotemporal dementia. Molecular Medicine Reports 2008;1:757-61. doi:10.3892/mmr-00000025

21 Meijboom R, Steketee RME, de Koning I, et al. Functional connectivity and microstructural white matter changes in phenocopy frontotemporal dementia. European Radiology 2017;27:1352-60. doi:10.1007/s00330-016-4490-4

22 Khan BK, Yokoyama JS, Takada LT, et al. Atypical, slowly progressive behavioural variant frontotemporal dementia associated with C9ORF72 hexanucleotide expansion. Journal of Neurology, Neurosurgery \& Psychiatry 2012;83:358-64. doi:10.1136/jnnp-2011-301883

23 Devenney E, Foxe D, Dobson-Stone C, et al. Clinical heterogeneity of the C9orf72 genetic mutation in frontotemporal dementia. Neurocase 2015;21:535-41. doi:10.1080/13554794.2014.951058

24 Rascovsky K, Hodges JR, Knopman D, et al. Sensitivity of revised diagnostic criteria for the behavioural variant of frontotemporal dementia. Brain 2011;134:2456-77. doi:10.1093/bra in/awr179

25 Khalil M, Teunissen CE, Otto M, et al. Neurofilaments as biomarkers in neurological disorders. Nature Reviews Neurology 2018;14:577-89. doi:10.1038/s41582-018-0058-z

26 Yuan A, Rao MV, Veeranna, et al. Neurofilaments and neurofilament proteins in health and disease. Cold Spring Harbor Perspectives in Biology 2017;9:1-24. doi:10.1101/cshperspect.a018309

27 Bridel C, van Wieringen WN, Zetterberg $\mathrm{H}$, et al. Diagnostic Value of Cerebrospinal Fluid Neurofilament Light Protein in Neurology: A Systematic Review and Meta-analysis. JAMA neurology 2019;76:1035-48.

28 Gaetani L, Blennow K, Calabresi P, et al. Neurofilament light chain as a biomarker in neurological disorders. Journal of Neurology, Neurosurgery \& Psychiatry 2019;90:870-81. doi:10.1136/jnnp-2018320106

29 Ashton NJ, Janelidze S, Al Khleifat A, et al. A multicentre validation study of the diagnostic value of plasma neurofilament light. Nat Commun 2021;12:3400. doi:10.1038/s41467-021-23620-z

30 Eratne D, Loi SM, Walia N, et al. A pilot study of the utility of cerebrospinal fluid neurofilament light chain in differentiating neurodegenerative from psychiatric disorders: A 'C-reactive protein' for psychiatrists and neurologists? Australian and New Zealand Journal of Psychiatry 2020;54:57-67. doi:10.1177/0004867419857811 
medRxiv preprint doi: https://doi.org/10.1101/2022.01.14.22269323; this version posted January 15, 2022. The copyright holder for this preprint (which was not certified by peer review) is the author/funder, who has granted medRxiv a license to display the preprint in perpetuity.

All rights reserved. No reuse allowed without permission.

31 Eratne D, Loi SM, Li QX, et al. Cerebrospinal fluid neurofilament light chain is elevated in Niemann-Pick type $C$ compared to psychiatric disorders and healthy controls and may be a marker of treatment response. Australian and New Zealand Journal of Psychiatry 2020;54:648-9. doi:10.1177/0004867419893431

32 Skillback T, Farahmand B, Bartlett JW, et al. CSF neurofilament light differs in neurodegenerative diseases and predicts severity and survival. Neurology 2014;83:1945-53. doi:10.1212/WNL.0000000000001015

33 Pijnenburg YAL, Janssen JC, Schoonenboom NSM, et al. CSF neurofilaments in frontotemporal dementia compared with early onset Alzheimer's disease and controls. Dementia and Geriatric Cognitive Disorders 2007;23:225-30. doi:10.1159/000099473

34 Forgrave LM, Ma M, Best JR, et al. The diagnostic performance of neurofilament light chain in CSF and blood for Alzheimer's disease, frontotemporal dementia, and amyotrophic lateral sclerosis: A systematic review and meta-analysis. Alzheimer's \&amp; Dementia: Diagnosis, Assessment \&amp; Disease Monitoring 2019;11:730-43. doi:10.1016/j.dadm.2019.08.009

35 Karantali E, Kazis D, Chatzikonstantinou S, et al. The role of neurofilament light chain in frontotemporal dementia: a meta-analysis. Aging Clinical and Experimental Research Published Online First: 2020. doi:10.1007/s40520-020-01554-8

36 Katisko K, Cajanus A, Jääskeläinen $\mathrm{O}$, et al. Serum neurofilament light chain is a discriminative biomarker between frontotemporal lobar degeneration and primary psychiatric disorders. Journal of Neurology 2020;267:162-7. doi:10.1007/s00415-019-09567-8

37 Al Shweiki MR, Steinacker P, Oeckl P, et al. Neurofilament light chain as a blood biomarker to differentiate psychiatric disorders from behavioural variant frontotemporal dementia. Journal of Psychiatric Research 2019;113:137-40. doi:10.1016/j.jpsychires.2019.03.019

38 Eratne D, Janelidze S, Malpas CB, et al. Plasma neurofilament light chain protein is not increased in treatment-resistant schizophrenia and first-degree relatives. Aust NZ J Psychiatry 2021; :In Press. doi:10.1177/00048674211058684

39 Bussè C, Pettenuzzo I, Pompanin S, et al. Psychiatric Phenocopy Syndrome of Behavioral Frontotemporal Dementia: Behavioral and Cognitive Fingerprint. J Alzheimers Dis 2019;72:1159-64. doi:10.3233/JAD190332

40 Wilke C, Preische O, Deuschle C, et al. Neurofilament light chain in FTD is elevated not only in cerebrospinal fluid, but also in serum. Journal of Neurology, Neurosurgery \& Psychiatry 2016;87:1-4. 


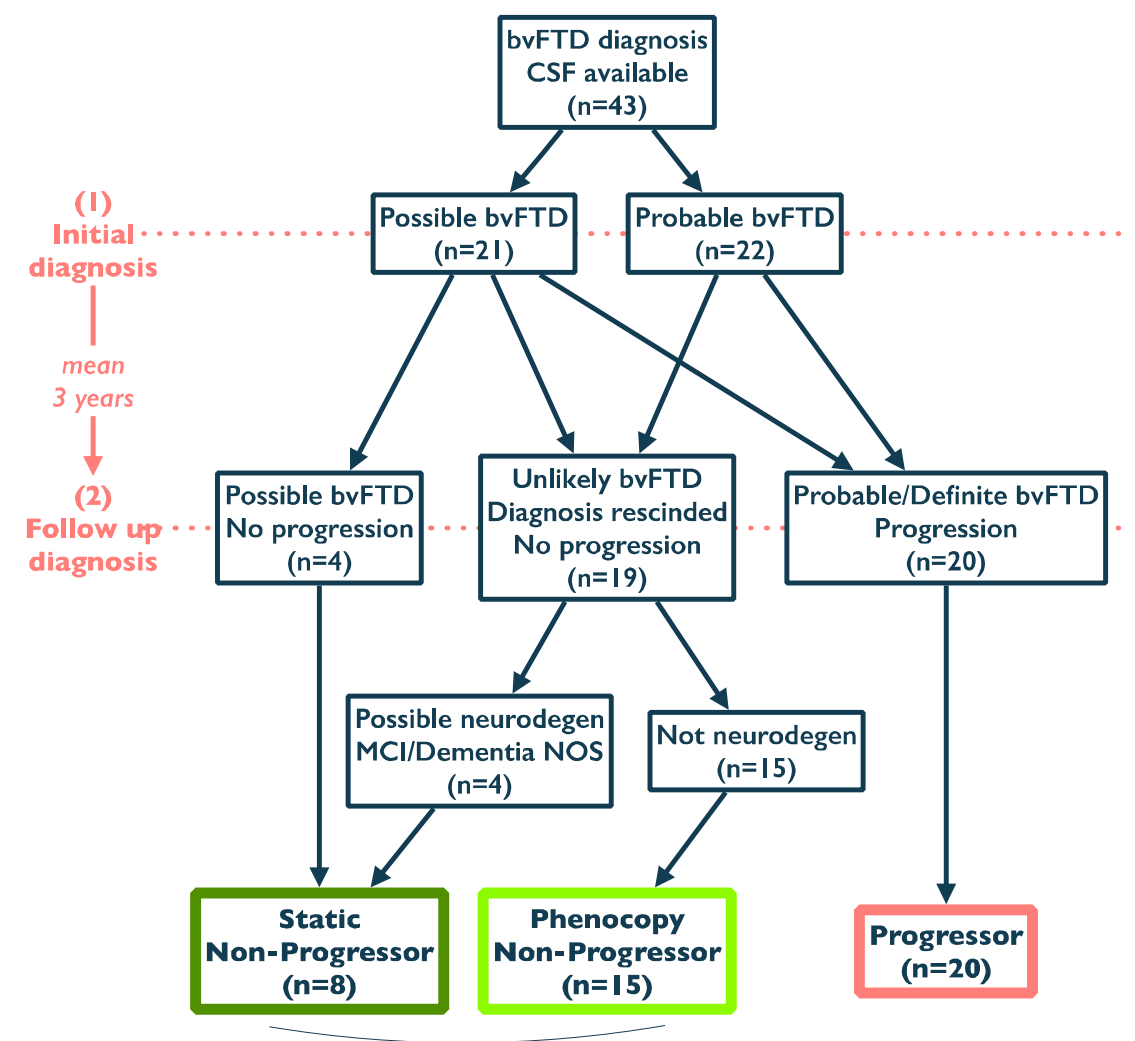

Figures and Tables

All Non Progressors $(n=23)$

\section{Figure 1. Diagnostic categorisation process}

Progressors were patients initially diagnosed with bvFTD, who had progression over time (clinical and/or neuroimaging and/or bedside cognitive/neuropsychological testing, and/or functioning), and retained the bvFTD diagnosis on follow up. Non-Progressors were patients initially diagnosed with bvFTD, but who did not show evidence of progression on follow up (clinical and/or neuroimaging and/or bedside cognitive/neuropsychological testing, and/or functioning). Non-Progressors were further subtyped in to Phenocopy Non-Progressors (the initial bvFTD was eventually completely rescinded in favour of a primary psychiatric/psychological/non-neurodegenerative diagnosis), and Static Non-Progressors (although bvFTD was though less likely, there was still a suspicion of 'something neurological/neurodegenerative going on' to explain static cognitive and functional impairments)

Final diagnoses for Phenocopy Non-Progressors included: post-traumatic stress disorder, maladaptive personality traits/personality disorders, psychotic disorder, bipolar disorder, subjective cognitive complaints secondary to psychological/psychiatric/substance use issues. Final diagnoses for Static Non-Progressors included: dementia not-otherwise-specified, mild cognitive impairment (vascular, unspecified non-amnestic), mood and personality disorders as potentially contributing factors.

bvFTD, behavioural variant frontotemporal dementia; $\mathrm{MCl}$, mild cognitive impairment; NOS, not otherwise specified 
medRxiv preprint doi: https://doi.org/10.1101/2022.01.14.22269323; this version posted January 15, 2022. The copyright holder for this preprint (which was not certified by peer review) is the author/funder, who has granted medRxiv a license to display the preprint in perpetuity.

All rights reserved. No reuse allowed without permission.

Table 1. Study population demographics and clinical information

\begin{tabular}{|c|c|c|c|c|c|}
\hline & Progressor & & $\begin{array}{l}\text { Non- } \\
\text { Progressor }\end{array}$ & & \\
\hline & $\begin{array}{l}\text { bvFTD } \\
\text { Progressor } \\
(n=20)\end{array}$ & $\begin{array}{l}\text { All Non- } \\
\text { Progressors } \\
(n=23)\end{array}$ & $\begin{array}{l}\text { Phenocopy } \\
\text { Non- } \\
\text { Progressor } \\
(\mathrm{n}=15)\end{array}$ & $\begin{array}{l}\text { Static Non- } \\
\text { Progressor } \\
(n=8)\end{array}$ & $\begin{array}{l}\text { Controls } \\
(n=20)\end{array}$ \\
\hline Age at CSF & $54[50,58]$ & $53[49,56]$ & $51[46,56]$ & $56[51,60]$ & $66[65,67]$ \\
\hline Female & $6(30 \%)$ & $5(22 \%)$ & $4(27 \%)$ & $1(14 \%)$ & $15(75 \%)$ \\
\hline $\begin{array}{l}\text { Age at cognitive } \\
\text { symptom onset }\end{array}$ & $52[48,55]$ & $50[46,54]$ & $49[44,53]$ & $52[49,57]$ & - \\
\hline $\begin{array}{l}\text { Duration } \\
\text { cognitive/behavioural } \\
\text { symptoms }\end{array}$ & $3[2,4]$ & $3[2,4]$ & $3[2,4]$ & $3[1,6]$ & - \\
\hline Length of follow-up & $3[2,4]$ & $3[2,4]$ & $3[2,4]$ & $3[2,4]$ & - \\
\hline $\begin{array}{l}\text { Initial diagnosis } \\
\text { possible bvFTD }\end{array}$ & $3(15 \%)$ & $18(78 \%)$ & $10(67 \%)$ & $8(100 \%)$ & - \\
\hline $\begin{array}{l}\text { Initial probable } \\
\text { bvFTD }\end{array}$ & $17(85 \%)$ & $5(22 \%)$ & $5(33 \%)$ & $0(0 \%)$ & - \\
\hline Final definite bvFTD ${ }^{a}$ & $7(35 \%)$ & - & - & - & - \\
\hline GAF score & $31-40$ & $41-50$ & $41-50$ & $41-50$ & - \\
\hline $\begin{array}{l}\text { Substance use } \\
\text { history }\end{array}$ & $4(20 \%)$ & $10(43 \%)$ & $7(47 \%)$ & $3(38 \%)$ & - \\
\hline $\begin{array}{l}\text { Previous psychiatric } \\
\text { diagnosis, } \mathbf{n}(\%)\end{array}$ & $7(35 \%)$ & $20(87 \%)$ & $13(87 \%)$ & $7(88 \%)$ & - \\
\hline Psychotic symptoms & $(25 \%)$ & $8(35 \%)$ & $6(40 \%)$ & $2(25 \%)$ & - \\
\hline $\begin{array}{l}\text { Other psychiatric } \\
\text { symptoms }\end{array}$ & $12(60 \%)$ & $19(83 \%)$ & $12(80 \%)$ & $7(88 \%)$ & - \\
\hline $\begin{array}{l}\text { New psychiatric } \\
\text { symptoms (within } 5 \\
\text { years) }\end{array}$ & $4(20 \%)$ & $14(61 \%)$ & $12(80 \%)$ & $2(25 \%)$ & - \\
\hline MRI abnormal & $20(100 \%)$ & $14(64 \%)$ & $10 / 14\left(71 \%^{\mathrm{a}}\right)$ & $4(50 \%)$ & - \\
\hline PET/SPECT & $18 / 19\left(95 \%{ }^{a}\right)$ & $20 / 22\left(91 \%^{a}\right)$ & $12 / 14\left(86 \%{ }^{a}\right)$ & $8(100 \%)$ & - \\
\hline
\end{tabular}


medRxiv preprint doi: https://doi.org/10.1101/2022.01.14.22269323; this version posted January 15, 2022. The copyright holder for this preprint (which was not certified by peer review) is the author/funder, who has granted medRxiv a license to display the preprint in perpetuity. All rights reserved. No reuse allowed without permission.

\begin{tabular}{|l|l|l|l|l|l|}
\hline abnormal & & & & \\
\hline Neurological exam & $14(70 \%)$ & $15(65 \%)$ & $9(60 \%)$ & $6(75 \%)$ & - \\
\hline $\begin{array}{l}\text { Neuropsychology } \\
\text { abnormal }\end{array}$ & $20(100 \%)$ & $21 / 21$ & & & \\
\hline NUCOG: total & & $\left(10 \%^{\mathrm{a}}\right)$ & $\left(100 \%{ }^{\mathrm{a}}\right)$ & & \\
& $70[64,76]$ & $77[71,82$ & $74[67,81]$ & $81[70,90]$ & - \\
\hline NUCOG: attention & $14[12,15]$ & $15[14,16]$ & $15[14,16]$ & $15[12,18]$ & - \\
\hline NUCOG: & $(\mathrm{n}=18)$ & $(\mathrm{n}=19)$ & $(\mathrm{n}=12)$ & \\
\hline visuoconstruction & $15[14,17]$ & $17[16,18]$ & $17[15,18]$ & $18[16,20]$ & - \\
\hline NUCOG: memory & $14[12,16]$ & $14[12,16]$ & $14[11,15]$ & $15[13,17]$ & - \\
\hline NUCOG: executive & $10[8,12]$ & $13[11,15]$ & $12[9,14]$ & $14[11,17]$ & - \\
\hline NUCOG: language & $17[15,18]$ & $18[17,19]$ & $18[16,19]$ & $18[17,20]$ & - \\
\hline
\end{tabular}

Unless otherwise stated, data is years [95\% confidence interval], or $\mathrm{n}(\%)$, at baseline/initial diagnosis of bvFTD. Values have been rounded to the nearest integer.

a: Genetic diagnoses: C9orf72 $(\mathrm{n}=5), \operatorname{MAPT}(\mathrm{n}=2)$

b: NUCOG is scored out of 100 , with a cutoff of $>80$ for 'normal' cognitive function. Each constituent domains is scored out of 20 .

bvFTD, behavioural variant frontotemporal dementia; CSF, cerebrospinal fluid; GAF, global assessment of functioning scale (lower scores indicate poorer functioning); Hx, history; NUCOG, Neuropsychiatry Unit Cognitive Assessment Tool. 
Table 2. Cerebrospinal fluid biomarker concentrations in bvFTD Progressors, Non-

\section{Progressors, and controls}

\begin{tabular}{|c|c|c|c|c|c|c|}
\hline & & & $\begin{array}{l}\text { Non- } \\
\text { Progressors }\end{array}$ & & & \\
\hline & $\begin{array}{l}\text { bvFTD } \\
\text { Progressors } \\
(\mathrm{n}=20)\end{array}$ & $\begin{array}{l}\text { Non- } \\
\text { Progressors } \\
\text { Total }(n=22)\end{array}$ & $\begin{array}{l}\text { bvFTD } \\
\text { Phenocopy } \\
\text { Non- } \\
\text { Progressors } \\
(n=15)\end{array}$ & $\begin{array}{l}\text { Static Non- } \\
\text { Progressors } \\
(n=8)\end{array}$ & $\begin{array}{l}\text { Controls } \\
(n=20)\end{array}$ & Difference $^{*}$ \\
\hline Group label & 1 & 2 & 3 & 4 & 5 & \\
\hline CSF NfL & $\begin{array}{l}2397[1607, \\
3332]\end{array}$ & $\begin{array}{l}554[461, \\
675]\end{array}$ & $459[385,539]$ & $\begin{array}{l}730[516, \\
940]\end{array}$ & $\begin{array}{l}523[461, \\
588]\end{array}$ & $1>2,3,4,5$ \\
\hline CSF T-tau & $\begin{array}{l}238[187 \\
298](n=18)\end{array}$ & $\begin{array}{l}180[135, \\
240](n=22)\end{array}$ & $\begin{array}{l}127[96,157] \\
(n=14)\end{array}$ & $\begin{array}{l}273[178, \\
404]\end{array}$ & $\begin{array}{l}182[161, \\
203]\end{array}$ & $1>3 ; 4>3$ \\
\hline CSF P-tau & $\begin{array}{l}38[32,46] \\
(n=18)\end{array}$ & $\begin{array}{l}40[32,51] \\
(n=22)\end{array}$ & $\begin{array}{l}32[26,40] \\
(n=14)\end{array}$ & $54[38,77]$ & $41[37,45]$ & $4>3$ \\
\hline CSF A $\beta 1-42$ & $\begin{array}{l}700[587, \\
825] \\
(n=18)\end{array}$ & $\begin{array}{l}718[637, \\
809](n=22)\end{array}$ & $\begin{array}{l}633[536,727] \\
(n=14)\end{array}$ & $\begin{array}{l}866[754, \\
1026]\end{array}$ & $\begin{array}{l}858 \text { [814, } \\
902]\end{array}$ & $4>3$ \\
\hline
\end{tabular}

Unless indicated, all values are means in $\mathrm{pg} / \mathrm{mL}$, with $95 \%$ bias-corrected and accelerated confidence intervals computed via bootstrapping with 1000 replicates. Values have been rounded to the nearest integer.

* details only differences in groups where general linear model mean difference confidence intervals do not capture the null hypothesis value

A $\beta 1$-42, $\beta$-amyloid peptide 1-42; CSF: cerebrospinal fluid; NfL: neurofilament light chain protein; $P$ tau: phosphorylated tau; T-tau: total tau. 
medRxiv preprint doi: https://doi.org/10.1101/2022.01.14.22269323; this version posted January 15, 2022. The copyright holder for this preprint (which was not certified by peer review) is the author/funder, who has granted medRxiv a license to display the preprint in perpetuity. All rights reserved. No reuse allowed without permission.

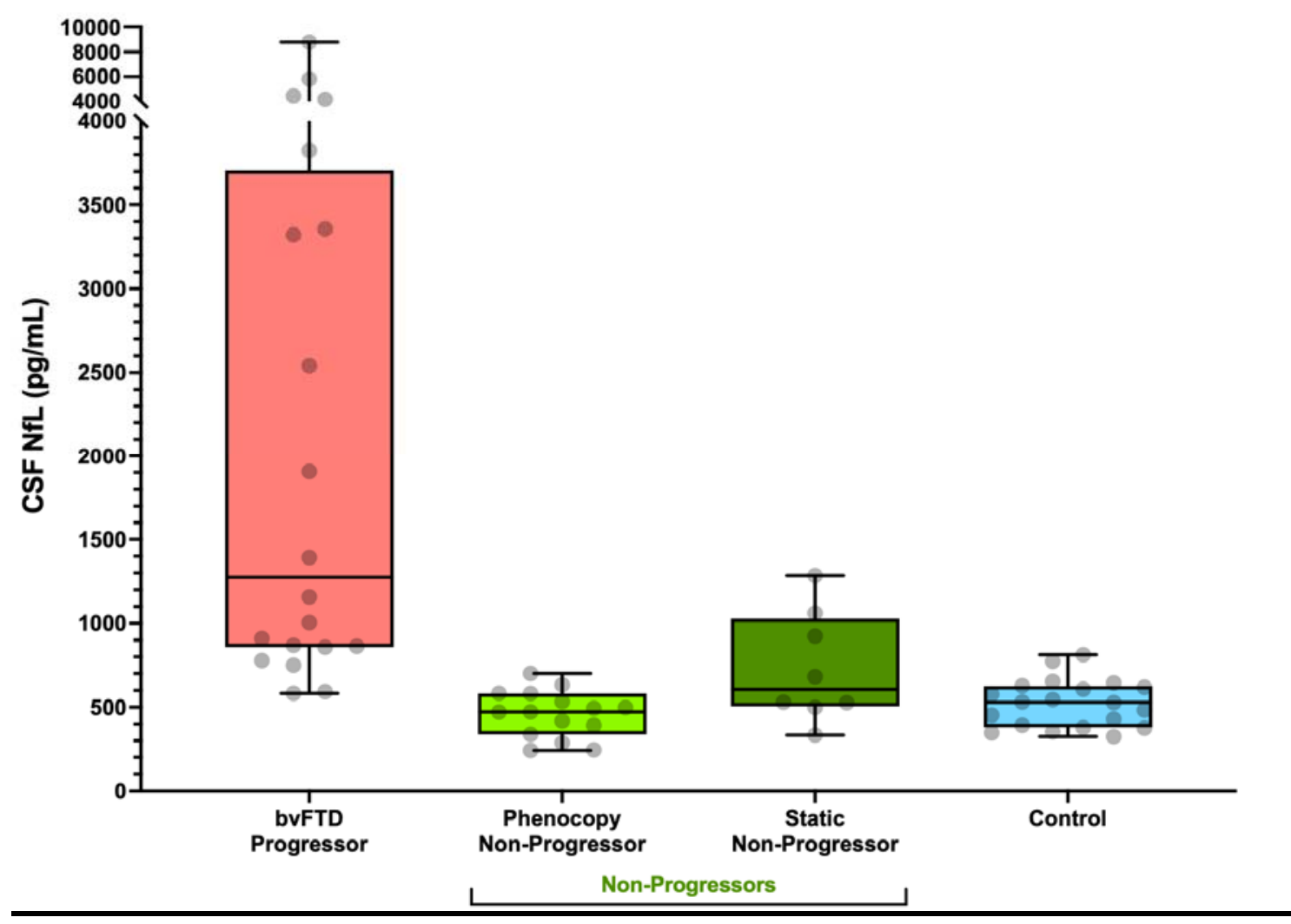

Figure 2. Box plot of cerebrospinal fluid (CSF) neurofilament light ( $\mathrm{NfL}$ ) between different

groups.

bvFTD, behavioural variant frontotemporal dementia; CSF, cerebrospinal fluid; NfL, neurofilament light. 
medRxiv preprint doi: https://doi.org/10.1101/2022.01.14.22269323; this version posted January 15, 2022. The copyright holder for this preprint (which was not certified by peer review) is the author/funder, who has granted medRxiv a license to display the preprint in perpetuity.

All rights reserved. No reuse allowed without permission.

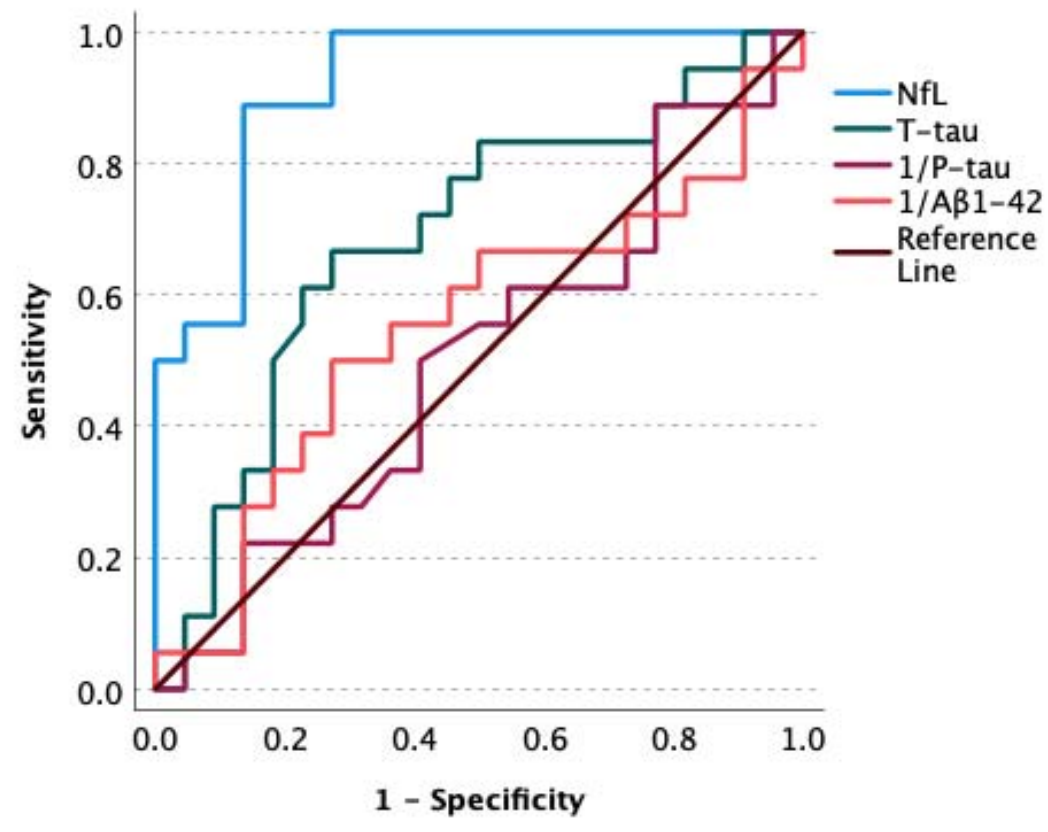

Figure 3. ROC Curve for behavioural variant frontotemporal dementia Progressors versus all Non-Progressors (comprising Phenocopy Non-Progressors and Static Non-Progressors)

ROC: receiver operating characteristic; NfL, neurofilament light; $A \beta 1-42, \beta$-amyloid peptide 1-42; Ptau, phosphorylated tau; T-tau, total tau. 


\section{APPENDIX 1: Collaborators}

Collaborators associated with The MiND Study Group:

\begin{tabular}{|c|c|c|}
\hline Name & Affiliations (separated by semi colon) & Title \\
\hline $\begin{array}{l}\text { Christiane } \\
\text { Stehmann }\end{array}$ & Australian National CJD Registry, The Florey Institute, Melbourne & $\mathrm{Dr}$ \\
\hline $\begin{array}{l}\text { Christopher } \\
\text { Fowler }\end{array}$ & $\begin{array}{l}\text { The Florey Institute of Neuroscience and Mental Health, The University of } \\
\text { Melbourne, Parkville, VIC }\end{array}$ & $\mathrm{Dr}$ \\
\hline Parsa Ravanfar & $\begin{array}{l}\text { Melbourne Neuropsychiatry Centre, Department of Psychiatry, The University } \\
\text { of Melbourne and Melbourne Health, Carlton South, VIC, Australia }\end{array}$ & $\mathrm{Dr}$ \\
\hline Sarah Farrand & $\begin{array}{l}\text { Neuropsychiatry, Royal Melbourne Hospital; Melbourne Neuropsychiatry } \\
\text { Centre \& Department of Psychiatry, University of Melbourne }\end{array}$ & $\mathrm{Dr}$ \\
\hline Rosie Watson & $\begin{array}{l}\text { Population Health and Immunity Division, The Walter and Eliza Hall Institute of } \\
\text { Medical Research, Parkville, Australia }\end{array}$ & A/Prof \\
\hline Nawaf Yassi & $\begin{array}{l}\text { Departments of Medicine and Neurology, Melbourne Brain Centre at the Royal } \\
\text { Melbourne Hospital, University of Melbourne, Parkville, Australia } \\
\text { Population Health and Immunity Division, The Walter and Eliza Hall Institute of } \\
\text { Medical Research, Parkville, Australia }\end{array}$ & A/Prof \\
\hline $\begin{array}{l}\text { Cath Kaylor- } \\
\text { Hughes }\end{array}$ & $\begin{array}{l}\text { Integrated Mental Health Team } \\
\text { Dept of General Practice } \\
\text { University of Melbourne, } 780 \text { Elizabeth St, Melbourne, } 3010\end{array}$ & Dr. \\
\hline Richard Kanaan & $\begin{array}{l}\text { Dept of Psychiatry, University of Melbourne, Austin Health, Heidelberg, VIC } \\
3084\end{array}$ & Prof. \\
\hline Piero Perucca & $\begin{array}{l}\text { Department of Medicine, Austin Health, The University of Melbourne; } \\
\text { Comprehensive Epilepsy Program, Austin Health; Department of Neuroscience, } \\
\text { Central Clinical School, Monash University; Department of Neurology, The } \\
\text { Royal Melbourne Hospital; Department of Neurology, Alfred Health, Melbourne, } \\
\text { VIC, Australia }\end{array}$ & A/Prof \\
\hline Lucy Vivash & $\begin{array}{l}\text { The Department of Neuroscience, The Central Clinical School, The Alfred } \\
\text { Hospital, Monash University; and The Departments of Medicine and Neurology, } \\
\text { The Royal Melbourne Hospital, The University of Melbourne, Victoria, Australia }\end{array}$ & $\mathrm{Dr}$ \\
\hline Rashida Ali & $\begin{array}{l}\text { Alfred Health; } \\
\text { Monash University } \\
\end{array}$ & Ms \\
\hline $\begin{array}{l}\text { Terence J. } \\
\text { O'Brien }\end{array}$ & $\begin{array}{l}\text { The Department of Neuroscience, The Central Clinical School, The Alfred } \\
\text { Hospital, Monash University; and The Departments of Medicine and Neurology, } \\
\text { The Royal Melbourne Hospital, The University of Melbourne, Victoria, Australia }\end{array}$ & Prof \\
\hline Andrew Evans & Neuropsychiatry, Royal Melbourne Hospital & A/Prof \\
\hline Anna King & The Wicking Dementia Centre, Tasmania & Professor \\
\hline Patrick Kwan & Alfred Hospital; Monash University, Melbourne & Professor \\
\hline Jane Gunn & Department of General Practice, The University of Melbourne & Professor \\
\hline Ilias Goranitis & $\begin{array}{l}\text { Health Economics Unit | Centre for Health Policy | Melbourne School of } \\
\text { Population and Global Health, The University of Melbourne }\end{array}$ & $\mathrm{Dr}$ \\
\hline Tianxin Pan & $\begin{array}{l}\text { Health Economics Unit | Centre for Health Policy | Melbourne School of } \\
\text { Population and Global Health, The University of Melbourne }\end{array}$ & $\mathrm{Dr}$ \\
\hline Brett Trounson & $\begin{array}{l}\text { The Florey Institute of Neuroscience and Mental Health, The University of } \\
\text { Melbourne, Parkville, VIC }\end{array}$ & $\mathrm{Mr}$ \\
\hline Christos Pantelis & $\begin{array}{l}\text { Melbourne Neuropsychiatry Centre \& Department of Psychiatry, University of } \\
\text { Melbourne, Parkville, VIC }\end{array}$ & Prof \\
\hline Stefanie Colella & Neuropsychiatry, Royal Melbourne Hospital & Ms \\
\hline Tomas Kalincik & $\begin{array}{l}\text { Clinical Outcomes Research Unit (CORe), Department of Medicine, } \\
\text { Department of Neurology, Royal Melbourne Hospital, Parkville, VIC, Australia }\end{array}$ & Prof \\
\hline Charles B & Clinical Outcomes Research Unit (CORe), Department of Medicine, & $\mathrm{Dr}$ \\
\hline
\end{tabular}


medRxiv preprint doi: https://doi.org/10.1101/2022.01.14.22269323; this version posted January 15, 2022. The copyright holder for this preprint (which was not certified by peer review) is the author/funder, who has granted medRxiv a license to display the preprint in perpetuity.

All rights reserved. No reuse allowed without permission.

\begin{tabular}{|l|l|l|}
\hline Malpas & Department of Neurology, Royal Melbourne Hospital, Parkville, VIC, Australia & \\
\hline Kaj Blennow & $\begin{array}{l}\text { Clinical Neurochemistry Lab, Inst. of Neuroscience and Physiology } \\
\text { University of Gothenburg, } \\
\text { Sahlgrenska University Hospital, Mölndal } \\
\text { Sweden }\end{array}$ & Prof \\
\hline Zenrik & $\begin{array}{l}\text { Department of Psychiatry and Neurochemistry, Institute of Neuroscience and } \\
\text { Physiology, the Sahlgrenska Academy at the University of Gothenburg, } \\
\text { Mölndal, Sweden; Clinical Neurochemistry Laboratory, Sahlgrenska University } \\
\text { Hospital, Mölndal, Sweden; Department of Neurodegenerative Disease, UCL } \\
\text { Institute of Neurology, Queen Square, London, UK; UK Dementia Research } \\
\end{array}$ & Prof \\
& Institute at UCL, London, UK; Hong Kong Center for Neurodegenerative & \\
\hline
\end{tabular}


medRxiv preprint doi: https://doi.org/10.1101/2022.01.14.22269323; this version posted January 15, 2022. The copyright holder for this preprint (which was not certified by peer review) is the author/funder, who has granted medRxiv a license to display the preprint in perpetuity.

All rights reserved. No reuse allowed without permission.

\section{Supplementary Material (see separate document)}

